\title{
SiM
}

\section{Bringing History Into Range Management}

\section{A Synthesis of a Symposium at the 65th Annual Meeting of the Society for Range Management}

\author{
By Matthew Allen Pearce
}

\section{On the Ground}

- Range scientists, managers, and practitioners can benefit by including history in their current monitoring and restoration efforts.

- A symposium at the 2012 SRM Annual Meeting explored three questions: How did certain assumptions toward the ecology and use of rangelands influence the development of range science and its application? How can land managers apply history to their current work? How can range science evolve in order to meet the challenges of the 21 st century?

- The symposium highlighted the need for an interdisciplinary approach toward understanding the past and confronting the future of rangelands.

Keywords: history, range management, rangelands.

Rangelands 35(1):22-26

doi: 10.2111/RANGELANDS-D-12-00038.1

(C) 2013 The Society for Range Management

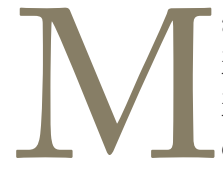

any range management professionals have an interest in the past, but they may have little idea as to how they can apply history to their current work. For over 100 years, range managers have worked steadily to improve rangelands and livestock raising practices in the American West and throughout the world. Yet the Society for Range Management (SRM), founded in 1948, is only six decades old-relatively young for a scientific association. I am happy to report that interest in this history has expanded within the Society in recent years. The plenary sessions for each of the three most recent annual meetings of SRM (Denver, Billings, and Spokane) featured at least one presentation about the history of rangelands or the range management profession. This trend, combined with the theme for the 2012 Spokane annual meeting-
"Lessons from the Past, Strategies for the Future"-compelled me to organize a symposium that could discuss range management's past and, more importantly, examine how we can use history to guide contemporary rangeland monitoring and restoration efforts.

This symposium, "Bringing History Into Range Management: Providing Perspective and Direction," had four goals. First, I aimed to show that interest in the history of range management was not limited only to specialists in that field. To accomplish this, I invited presenters from various backgrounds with a shared common interest in the history and future of rangelands. The symposium featured three historians, a geographer, and three range management specialists; some of whom are well recognized in their respective fields and others just emerging. Table 1 lists the symposium's topics and speakers, along with their affiliations. Assembling this interdisciplinary panel would, in turn, help stimulate further interest in the history of range management within SRM, thus meeting my second goal for the symposium. Third, I wanted the symposium to combine an examination of range management's past with discussions of how SRM members could apply history to their own work. Finally, no symposium of this nature could be complete without a conversation about where range management should go in its next 100 years. The field has come a long way from its origins in the deteriorated western rangelands of the late 19th century. ${ }^{1,2}$ There is still much work to do, however. The final goal for the symposium was to address how range science must adapt to the challenges of a new millennium in which we find rangelands and livestock enmeshed in a global economy and in a world with less grass.

Discussion during the symposium centered on three important questions. First, how did certain assumptions toward the ecology and use of rangelands influence the development of range science and its application on western landscapes? Second, how can land managers apply history to their current work? Finally, how will range science evolve in the 21st century? Debate of these questions provided in- 
dividuals with lessons from the past from which to develop strategies for the future, linking to the theme of the Spokane annual meeting. It also encouraged them to take a step back from their particular locales or specific research projects and consider the broader history of range management, of which they are a part.

SRM members must never forget how ideas regarding the use and development of rangelands, combined with the politics involved in land management and livestock grazing, influenced the evolution of range science and policy. Range management, originally conceived as "the science and art of obtaining maximum livestock production from range land consistent with conservation of the land resources," did not develop in a vacuum. ${ }^{3}$ Indeed, in order to understand the past, present, and future of range management, one has to appreciate the intellectual and political milieu from which it emerged. Several presentations discussed this fact from a variety of angles, including the theories of Frederic Clements, the halls of Congress, and the rangelands of the North American West.

Two ideas in particular provided the foundation for range science and public lands grazing policy (Sayre, Table 1). First, for much of the 20th century, federal scientists and ranchers alike assumed that the western range was chiefly valuable for livestock grazing. Second, within the context of Frederic Clements's theories of plant succession and climax, early range scientists, most notably Arthur W. Sampson, argued that they could use livestock as tools to improve rangeland resources and increase animal productivity. In other words, scientists like Sampson suggested that better management and stock handling practices could rehabilitate deteriorated rangelands.

These ideas regarding the use and ecology of western rangelands combined with the ambition of certain politicians to create range management policy, as seen during the passage of the Taylor Grazing Act of 1934 (Pearce, Table 1). The act organized much of the nation's remaining public domain rangelands into grazing districts and created the Division of Grazing (forerunner to the Bureau of Land Management [BLM]) to administer them. In part, the act was a result of the assumption that unclaimed public domain lands were chiefly valuable for grazing and that they could be improved through proper management. The Taylor Grazing Act was also a product of the New Deal conservation movement and western reluctance regarding permanent federal management of the public lands.

The fundamental premise of the New Deal conservation movement, best personified by Secretary of the Interior Harold L. Ickes, was that rural poverty and poor land use practices such as overgrazing on the public domain contributed to the Great Depression. Conservationists believed that federal regulation, with local cooperation, could help rehabilitate these rural landscapes and the industries dependent upon them. Furthermore, Harold Ickes desired to transform the Department of the Interior into a Department of Conserva- tion that would administer all federal activities that involved natural resource management. This ambition, combined with the fact that the public domain already lay under the jurisdiction of the General Land Office, resulted in the Department of the Interior managing these rangelands rather than the Department of Agriculture. Edward T. Taylor, representative from Colorado, also believed that federal management could improve public domain grazing lands. Yet he also argued that, upon doing so, the federal government should relinquish its administration of public rangelands to the respective states or private individuals. In fact, the final version of the Taylor Grazing Act stipulated that the federal government was to manage the public domain "pending its final disposal" to state or private ownership. ${ }^{4}$ Harold Ickes and Edward Taylor were similar in their ideas that public domain rangelands were chiefly valuable for livestock grazing and that scientific management could improve them, but they differed on whether federal supervision of the public domain should be permanent. Nonetheless, the Taylor Grazing Act formalized these assumptions toward the use and management of public rangelands and established the political-intellectual fabric under which subsequent generations of federal officials and ranchers worked.

This framework had to adapt to local circumstances, however. Two presentations in particular examined the challenges land managers faced in areas where livestock grazing was not considered the chief use of the range. Organ Pipe Cactus National Monument, located in southern Arizona, was one of these places (Pinto, Table 1). President Franklin Delano Roosevelt proclaimed the monument's creation in 1937. Yet Robert Lee Gray and his family, who grazed livestock within its boundaries, continuously frustrated National Park Service efforts to develop the monument's scenic resources and protect its rare plant species, most notably the organ pipe cactus (Stenocereus thurberi). This case study testifies to the importance of politics in range management because the Gray family obtained a lifetime grazing permit inside the monument with the help of Arizona Senator Carl Hayden. For the next several decades, monument officials with no experience in range management worked to preserve the landscape's distinct vegetation while the Gray family continued to run up to 1,500 cattle in the area. This process continued until the death of the last Gray family member and the final removal of livestock from the monument in the mid-1970s. Throughout this period, however, rangelands within Organ Pipe Cactus National Monument steadily deteriorated and they have yet to recover even with the absence of livestock.

Range management in North American badlands brought its fair share of challenges as well (Evans, Table 1). Many of these areas-characterized by excessive erosion, ridges, and deep gullies - experienced the effects of livestock grazing during the late 19th century. After all, Theodore Roosevelt acquired fame by running cattle in the North Dakota badlands in what is now Theodore Roosevelt National Park. Livestock or other large ungulates such as bison continue to 
live in many badlands today. Complicating the range management of these areas is the fact that several governing agencies manage them, including the National Park Service, the Forest Service (Pawnee Buttes Badlands within the Pawnee National Grasslands, northeastern Colorado), the BLM (Terry Badlands, eastern Montana), and state conservation organizations (Cathedral Gorges State Park, Nevada). Other badlands are privately owned, such as Hell's Half Acre in central Wyoming. As a result, range management in the badlands exists under a variety of circumstances. In Theodore Roosevelt National Park, it involves management of the park's bison herd. Meanwhile, The Nature Conservancy's range management program at Four Canyon Preserve in western Oklahoma involves the eradication of eastern red cedar (Juniperus virginiana). In contrast, range management no longer exists in Palo Duro Canyon State Park, Texas, because the park focuses primarily on outdoor recreation and tourism despite the area's important place in the history of the western range livestock industry as the site of Charles Goodnight's JA Ranch.

In addition to discussing the political-intellectual foundations of range management and its application to local areas in past and present circumstances, the symposium addressed how SRM members can apply history as they determine current management strategies and objectives. This constituted the most important part of the symposium. In order to apply past range survey data or photographs, one must understand the context under which they were first collected or taken. The Parker 3-step method, for example, was the first comprehensive and repeatable range survey technique implemented by the Forest Service (Ruyle, Table 1). In 1948, the agency tasked Kenneth W. Parker, who had studied range science under Arthur Sampson, with the creation of a survey system that was simple to conduct, easy to repeat, and acceptable to permittees. The result was the Parker 3-step, which provided data regarding vegetation composition and trend for many national forest ranges. It continues to be a method that many members of SRM are familiar with today even though it is no longer in use. The logic behind its creation was rooted in Clementsian ecology and the assumption that all rangelands were chiefly valuable for livestock grazing. After all, the purpose of these range surveys was to determine the "maximum practical condition" of forest grazing lands by examining composition and trend, thus reinforcing notions of plant succession and the definition of range management established by Laurence Stoddart and Arthur Smith. Nonetheless, the data accumulated under the Parker 3-step method constitutes the longest-term range monitoring data sets for most Forest Service grazing allotments and some managed by the BLM. These data can provide an index of how rangelands have changed over time, especially in terms of ground cover and vegetation type. Indeed, the material collected by the Parker 3-step, combined with its extensive photographic record, comprises a treasure trove of past research data that current range managers should utilize rather than throw away.
Photographs provide another way for range managers to apply history to their current work (Bradford, Table 1). One can find historic range photographs in a variety of places, including local field offices, nearby museums, and archives. Of further benefit to potential range managers-turned-historians is the fact that an increasing number of photograph collections are available digitally, including those of the Denver Public Library, the US Geological Survey, and even the National Archives. Research in historical photographs, in conjunction with past range survey data, provides range managers with an understanding of how a particular landscape has changed over time. They are also useful tools in a variety of situations. For one thing, these photographs, when combined with recent ones from the same photo point, are an important visual aid when land managers and permittees discuss changes in grazing strategies. A series of photographs depicting significant changes in vegetation composition over time could help convince a permittee to agree to reduce livestock numbers or grazing intensity on their allotment.

Photos can also prove useful when interacting with the public over issues such as livestock grazing on federal lands. Many people, ranchers and environmentalists included, tend to believe that all western rangelands existed in a climax condition prior to the arrival of domestic livestock and widespread overgrazing. Antigrazing advocates combine this assumption with the argument that the removal of such animals from public rangelands will result in the land's return to presettlement conditions (Sayre, Table 1). Expert use of photographs and the historical record can help dispel these notions. In particular, photos that show how a landscape improved by altering its management and not by removing livestock altogether can be useful for interactions either with permittees skeptical of changes in their grazing rotation or with environmentalists suspicious of the ecological and economic benefits of public lands grazing.

Use of past Parker 3-step data and photographs complements other efforts in range science to use history when determining current land management and monitoring strategies. For example, a coalition of BLM employees and faculty at New Mexico State University and the Jornada Experimental Range has recently digitized maps made by a Civilian Conservation Corps range survey crew in southern New Mexico in 1936-1937. ${ }^{5}$ The data recorded in these surveys pertained to vegetation composition and palatability for livestock, topography, and the existence of any improvements or infrastructure. Participants in this digitization effort note that the records these surveyors compiled constitute a valuable baseline from which to examine how range resources in the area have changed since its organization into a grazing district in the mid-1930s. The use of historic Parker range survey data or photographs is no different. The best land management decisions are those grounded in a firm understanding of the past. Indeed, historic maps, range survey data, and photographs all constitute a "legacy resource" that should be preserved and used to determine how range conditions have changed over time. ${ }^{5}$ 
There is no doubt that an understanding of the politicalintellectual foundations of range management and greater appreciation of past range survey data or photographs can make SRM members better land managers. Such knowledge of history can help improve interactions with our constituents, whether they are students, permittees, or the public at large. Yet how can we apply the lessons of the past when addressing current problems that face rangelands and livestock production in the United States and throughout the world? The majority of symposium presenters discussed how past range scientists, ranchers, and politicians reacted to problems posed by deteriorated rangelands. These responses included the application of plant succession theory, the implementation of policies like the Taylor Grazing Act, and the introduction of new range survey techniques like the Parker 3-step. Despite these measures and the creation of a simple definition for the field, range management has become increasingly difficult in the face of new ideas that undermined Clementsian ecology and as managers came to recognize that they faced a resource characterized not by stability but by unpredictable change.

The symposium proposed a possible solution to the dilemmas that confront range science in the 21st century. Not only must land managers recognize the dynamic attributes of the resource in which they work, range management itself must expand its spatial scale and adapt its research to a world with less grass, an increasing number of exotic species, and more productive livestock (Havstad, Table 1). To do this, managers need to rethink how the range resource works. Much like the human genome or a computer, all landscapes have repeating units, or "codes." Use of the ecological site descriptions within the Major Land Resource Areas database can help range managers distinguish the differences in vegetation and soil composition between certain areas.

Range research within these sites must adopt several characteristics. First, all researchers must approach the range with an understanding of its past, incorporating past range survey data. They should also undertake an investigation of the written, oral, and photographic records. When doing so, researchers and land managers must show a respect toward local knowledge of the landscape. After all, the people who live and work in these rangelands have valuable suggestions and experiences to offer. The testing of hypotheses in land management should incorporate this local knowledge, be site-specific, and always be transparent to the public and affected parties.

An approach to range research along these lines, this symposium suggests, can provide a greater understanding of the dynamics within rangeland ecosystems throughout the West-indeed, the world-in a manner that reincorporates on-the-ground knowledge and management back into scientific research. This approach also ensures a place for history, as it depends upon an understanding of how resources and their use have changed over time. Moreover, this method should encourage research throughout the western range, in field offices as well as at state universities or stations like the Jornada Experimental Range in southern New Mexico. U1timately, such a strategy could reunite the art and science of range management and make the field more responsive to the demands for rangeland resources in the 21st century.

Table 1. Speakers and topics from the symposium "Bringing History Into Range Management:

Providing Perspective and Direction"

Matthew Pearce, University of Oklahoma, Norman, OK, USA: "The Passage of the Taylor Grazing Act of 1934 and Its Legacy"

Robin Pinto, University of Arizona, Tucson, AZ, USA: "Grazing Conflict and the National Park Service: Range History in Organ Pipe Cactus National Monument"

Sterling Evans, University of Oklahoma, Norman, OK, USA: "Grazing in the Rough: The History of Land Use and Rangelands Management in the Badlands of the North American West"

George Ruyle, University of Arizona, Tucson, AZ, USA: "Historical Development and Application of the Parker 3-Step Method for Rangeland Monitoring"

David Bradford, US Forest Service, Paonia, CO, USA: "Using Historic Surveys and Photographs to Evaluate National Forest Rangelands"

Nathan Sayre, University of California, Berkeley, CA, USA: "Historical Roots of the Rangeland Conflict: Overcoming Structural and Intellectual Anachronisms"

Kris Havstad, Jornada Experimental Range, Las Cruces, NM, USA: "New Research Themes after a Century of Range Science: Post-modern Science for 21 st Century Landscapes" 
Range science has come a long way since its inception in the late 19th century. Most SRM members agree that the field's founding principles - the application of science and better livestock handling practices-has helped rangelands improve in quality and carrying capacity. As rangelands and their uses have changed over time, the definition of the field has expanded to better account for these new interests and challenges. Today, many people realize that healthy rangelands provide more than just forage for livestock. They help maintain our nation's watersheds, offer opportunities for outdoor recreation, and provide wildlife habitat. Land managers must also keep an eye out for the plants, microorganisms, and soil that constitute the foundation for all rangelands. ${ }^{6}$ This recognition of how our use and understanding of rangelands has evolved can help SRM members move beyond the simple question of whether they have improved to consider the more important issue of how rangelands, their uses, and the politics associated with them have and will continue to change. Rangelands remain a dynamic natural resource. Range conditions will always fluctuate. As a result, range managers must be ready to adjust. The goal of this symposium was not simply to examine whether rangelands have improved since the late 19th century. Its purpose was to provide participants with a better understanding of the history and ecology of rangelands and suggest tools and ideas to help SRM members address current challenges and possibly even anticipate new ones.

In sum, then, this symposium highlighted the theme for the 2012 annual meeting by facilitating discussions of the political-intellectual foundations of range management, the application of history to address current land management dilemmas, and the future of range research. In the process, it revealed the beauty of SRM and why, as a historian, I find attending its annual meetings so refreshing. Like most sessions in Spokane, this symposium introduced the latest research in range management, in this case that pertaining to its history and the benefits of historical research in current monitoring and restoration efforts. Yet the composition of the symposium-both presenters and spectators-best reflected the organization's mission to welcome anyone dedicated to or interested in the advancement of "the science and art of grazing land management," an endeavor SRM embarked upon following its official inception in $1948 .^{7}$ If the founders of our organization had been in the room, they would have seen individuals from various disciplines and degrees of expertise gathering to understand a resource about which they are passionate. The symposium accomplished much toward that process. It examined where the range management profession has been, including its intellectual origins, political manifestations, and implementation in a variety of landscapes. It also emphasized how land managers can apply history and, furthermore, how knowledge of range management's past can help facilitate the "postmodern" turn in range science. In short, the symposium was a testament to the benefits of an interdisciplinary approach toward understanding our past and confronting our future.

\section{Acknowledgments}

Special thanks to my fellow symposium presenters for their willingness to participate and keen insights. I would also like to thank Lori Hidinger for taking an interest in this project and for her comments, in addition to those from another anonymous reviewer.

\section{References}

1. Galbraith, W., and E. Anderson. 1971. Grazing history of the Northwest. Journal of Range Management 24:6-12.

2. Holecheк, J. 1981. A brief history of range management in the United States. Rangelands 3:16-18.

3. Stoddart, L. A., And A. D. Smith. 1955. Range management. New York, NY, USA: McGraw-Hill Book Co. 433 p.

4. Taylor Grazing Act. 1934. US Statutes 48:1269-1275.

5. Skaggs, R., Z. Edwards, B. T. Bestelmeyer, J. B. Wright, J. Williamson, And P. Smith. 2011. Vegetation maps at the passage of the Taylor Grazing Act (1934): a baseline to evaluate rangeland change after a regime shift. Rangelands 33(1):13-19.

6. National Research Council, Committee On Rangeland Classification. 1994. Rangeland health: new methods to classify, inventory, and monitor rangelands. Washington, DC, USA: National Academy Press. 180 p.

7. American Society of Range Management. 1948. Constitution and by-laws of American Society of Range Management. Journal of Range Management 1:35.

Author is a PhD Candidate, Dept of History, University of Oklahoma, Norman, OK 73019, USA, Matthew.A.Pearce-1@ou.edu. 